\title{
Flood map development by coupling satellite maps and three-dimensional drafting software: Case study of the Sarawak River Basin
}

\author{
Kuok King Kuok ${ }^{1 *}$, Liew Zun Ziet ${ }^{1}$ and Chiu PoChan ${ }^{2}$ \\ ${ }^{1}$ School of Engineering, Computing and Science, Swinburne University of Technology Sarawak Campus, \\ Jalan Simpang Tiga, 93350 Kuching, Sarawak, Malaysia \\ ${ }^{2}$ Department of Information System, Faculty of Computer Science and Information Technology, \\ University Malaysia Sarawak, 94300 Samarahan, Sarawak, Malaysia
}

\begin{abstract}
Flood maps are important for local authorities in designing mitigation plans to minimise damage and loss due to flooding. In recent years, flood events in the Sarawak River Basin, Malaysia have caused damage to property, loss of life and disruption of productive activities. Currently, the available flood map for Sarawak River Basin is generated using InfoWorks River Simulation (InfoWorks RS) and spot levels are captured using the Light Detection and Ranging (LiDAR) system. However, the high cost of this flood mapping technique has motivated the development of an advanced but low-cost flood mapping method. This study was carried out to test the feasibility of using Google Earth coupled with Autocad Civil 3D in generating flood maps. Google Earth was used to obtain the elevation data, while Autocad Civil 3D was used to plot the water level surface. Data for the maximum water level, recorded since 1960, for 12 water level stations were fed into the model for flood map generation. This research confirmed that Autocad Civil 3D coupled with Google Earth is feasible for generating an updated and accurate flood map, after comparison with 2 flood maps developed previously.
\end{abstract}

Keywords: Autocad Civil 3D, flood map, Google Earth

\section{Introduction}

Flood maps are maps indicating the flood-prone areas and their expected water levels, based on flow models or past records(Jones, 2004).Flood maps are generated to provide communities with flood-risk information and also for development and evacuation purposes. The maps enable local authorities, organisations and developers to manage the flood risk efficiently and effectively. In addition, flood maps are used for designing drainage system as well as developing plans for mitigating flood occurrence.

Flood mapping is essential in countries with frequent and high precipitation, as well as countries affected by critical climate systems such as typhoons, and the El Nino and La Nina oscillations. In the past, heavy rainfall has led to disastrous flood events in Sarawak River Basin, Malaysia, especially during the Northeast Monsoon from October to February (River Basin Initiative Malaysia, 2002-2011). The ineffective drainage system in the undeveloped interior parts of Sarawak make the situation worse, and causes the rural areas to be the most susceptible to flooding during the rainy season.

Various methods have been developed for generating flood maps. Jones (2004)of the United States Geological Survey (USGS) presents a method utilising the TRIMR2D hydraulic model coupled with elevation data obtained from Light Detection and Ranging (LiDAR) to generate flood maps in the

* To whom all correspondence should be addressed.

+6082-296850; e-mail: kelvinkuok100@gmail.com Received 12 January 2012; accepted in revised form 20 December 2012.
USA. The Department of Irrigation and Drainage Sarawak (DIDS) has generated a flood map for the Sarawak River Basin by integrating InfoWorks River Simulation (InfoWorks RS) and LiDAR systems for capturing spot levels. However, the resulting flood map was produced at an expense of approx. 330000 USD, which is not cost-effective. A detailed survey of the river cross sections, which is a time and labour-intensive activity, and elevation data obtained from 1:50 000 topographical maps was required for generating the flood maps using InfoWorks RS (Hii et al.,2009; Bustami et al., 2011; Mah et al.,2011). Flood maps for other river basins in Sarawak are still plotted manually using outdated 1:50 000 topographical maps (KTA Tenaga, 2003).

Therefore, this study was conducted to investigate the feasibility of using updated Digital Elevation Model (DEM) data retrieved from Google Earth, and coupled with Autocad Civil 3D, to generate a 100 -year flood map. The selected study area was Sarawak River Basin.

\section{Study area}

Malaysia is located within the tropical rainforest climatic and vegetation region, and experiences heavy and frequent rainfall throughout the year, with no significant dry season. The average annual rainfall for Sarawak State is approximately 3850 $\mathrm{mm}$ (River Basin Initiative Malaysia, 2002-2011). The state receives most of its rainfall during the Northeast Monsoon from October to February every year. Kuching city, located within Sarawak River Basin, experiences its maximum precipitation in January (approx. $700 \mathrm{~mm}$ in the year 2009) (Fig. 1). This extremely high rainfall contributes to flash flooding. 


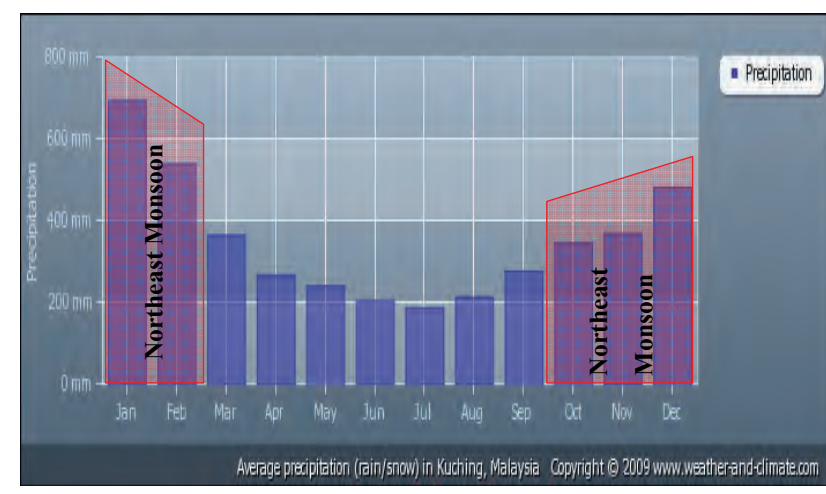

Figure 1

Average precipitation for Kuching in 2009

(World Weather and Climate Information, 2010-2011)

Sarawak River Basin is located in the southern part of Sarawak State (Fig. 2), and comprises of 2 sub-basins: Sarawak Kiri River and Sarawak Kanan River. Sarawak River Basin covers an area of $2459 \mathrm{~km}^{2}$ and the main river extends over a length of $120 \mathrm{~km}$ (Department of Irrigation and Drainage Malaysia, 2011). The confluence of the two tributaries occurs at Batu Kitang. The river passes through Kuching City, literally splitting the city into northern and southern regions, and eventually empties into the South China Sea.

\section{Methodology}

In this study, Google Earth was coupled with Autocad Civil 3D for generating a flood map. Google Earth was used to obtain the elevation data for Sarawak River Basin, whereas Autocad Civil 3D was used to plot the flood map.

\section{Google Earth}

Google Earth is a virtual globe-based geographical information program used widely around the world to acquire geospatial information, and to determine the position of topographical and built features (Google Earth, 2011). The geospatial information is mapped by the superimposition of images acquired from aerial photography, satellite imagery and a 3D GIS virtual globe.

Google Earth provides high resolution maps and topographical areas with Digital Elevation Model (DEM) data acquired from the Shuttle Radar Topography Mission (SRTM) (Farr et al., 2007; Google Earth Community, 2006).

SRTM is an international geospatial information-delivering project led by the United States National GeospatialIntelligence Agency (NGA) and the United States National Aeronautics and Space Administration (NASA). The project utilised a specially modified radar system to acquire elevation data on a near-global scale to produce a high-resolution digital topographic database of Earth (Farr et al., 2007). An elevation model of Earth has been derived from SRTM data. Google Earth can be accessed and obtained freely over the Internet and is widely used in geographic information systems.

\section{Autocad Civil 3D}

Autocad Civil 3D is specially designed to support all types of civil engineering projects. The software utilises 2 and 3-dimensional, dynamic, model-based design technology to aid in design and planning (AutoCAD $\mathbb{R} ;$ ACA Pacific, 2012). In

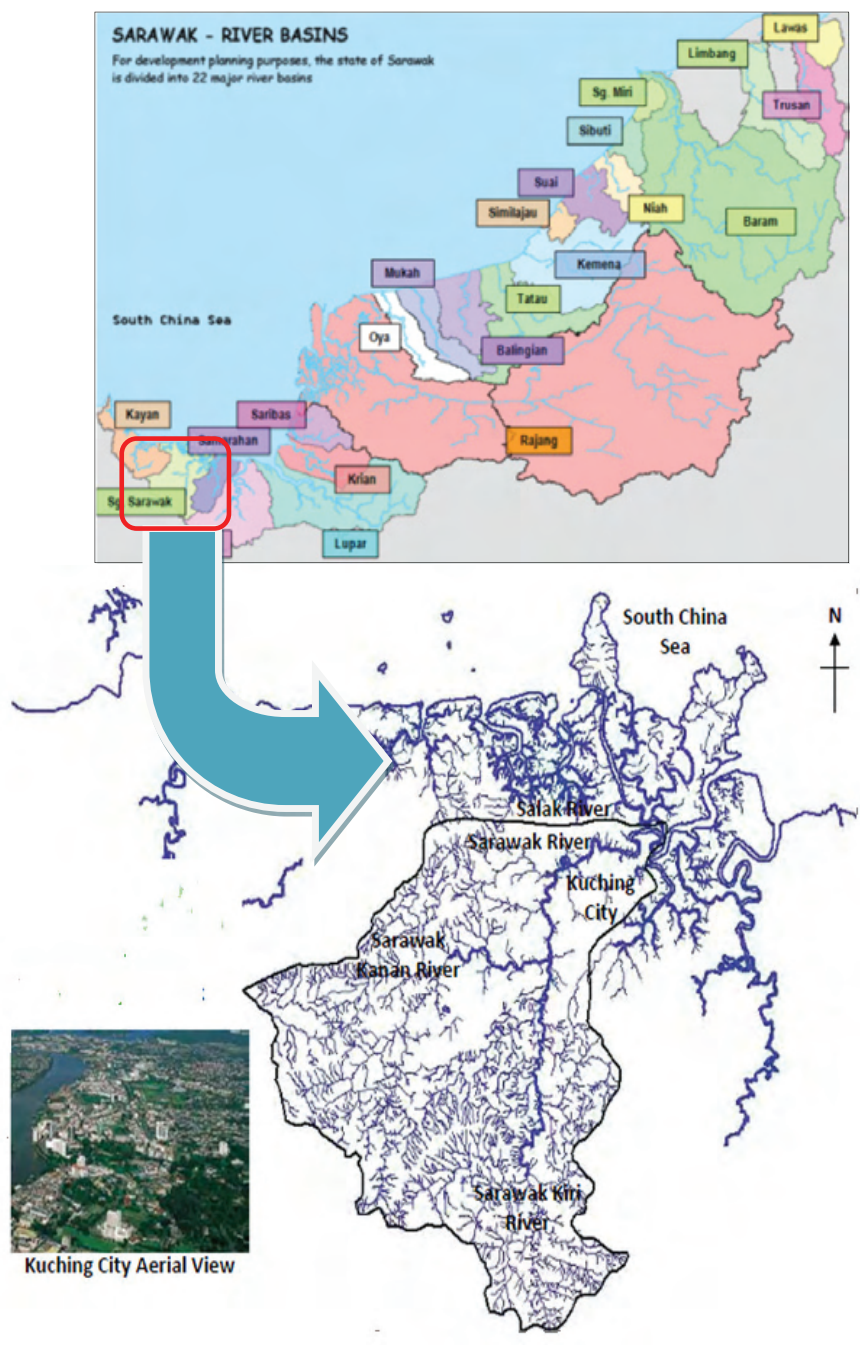

Figure 2

River basins in Sarawak

(Department of Irrigation and Drainage Sarawak, 2011)

addition, the software also assists users to generate and evaluate designs quickly and accurately.

Autocad Civil 3D enables the importation of geospatial information from Google Earth. Basically, the files imported from Google Earth to Autocad Civil 3D consist of 2 surfaces -base map imagery and a Triangulated Irregular Network (TIN) surface. Base map imagery is aerial imagery showing the nature of the terrain and built features on the ground, while the TIN surface shows the contours or elevation data for the ground surface in a set of contiguous, non-overlapping triangles. The accuracy of the elevation data derived is a critical factor for determining the feasibility and accuracy of flood map generation.

\section{Flood map development steps}

The process of developing a flood map by integrating Autocad Civil 3D and Google Earth takes place in 6 steps (Fig. 3), described here for the development of a flood map for Sarawak River Basin Firstly, the boundary of Sarawak River Basin and the main rivers was delineated on the Google Earth image. The Google Earth Image and TIN Surface were then imported into Autocad Civil 3D. The course of the rivers was plotted and the data for maximum water levels recorded since 1960 for 12 


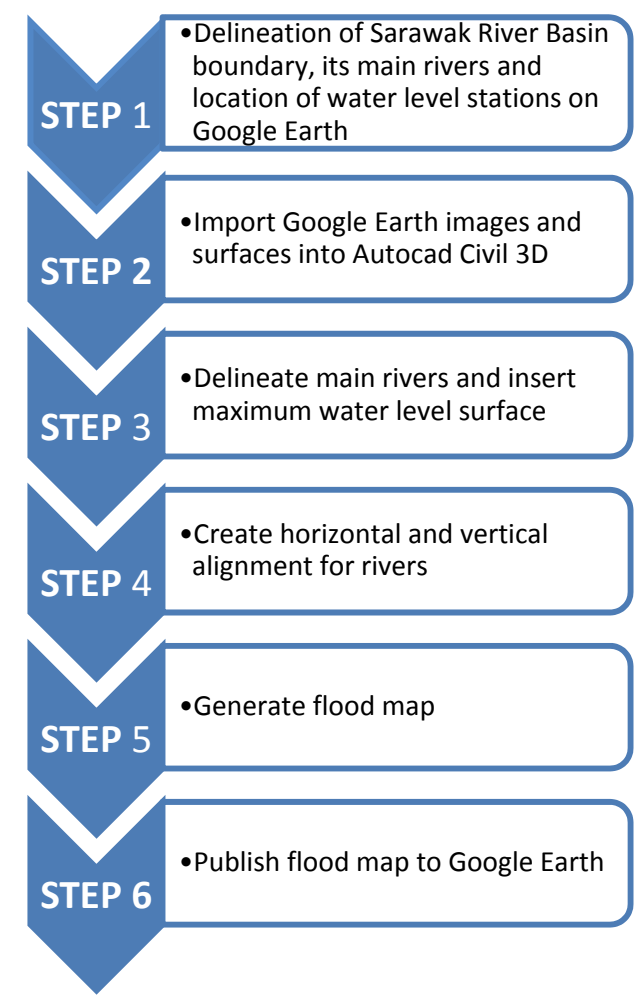

Figure 3

Steps in flood map development by coupling Autocad Civil 3D and Google Earth

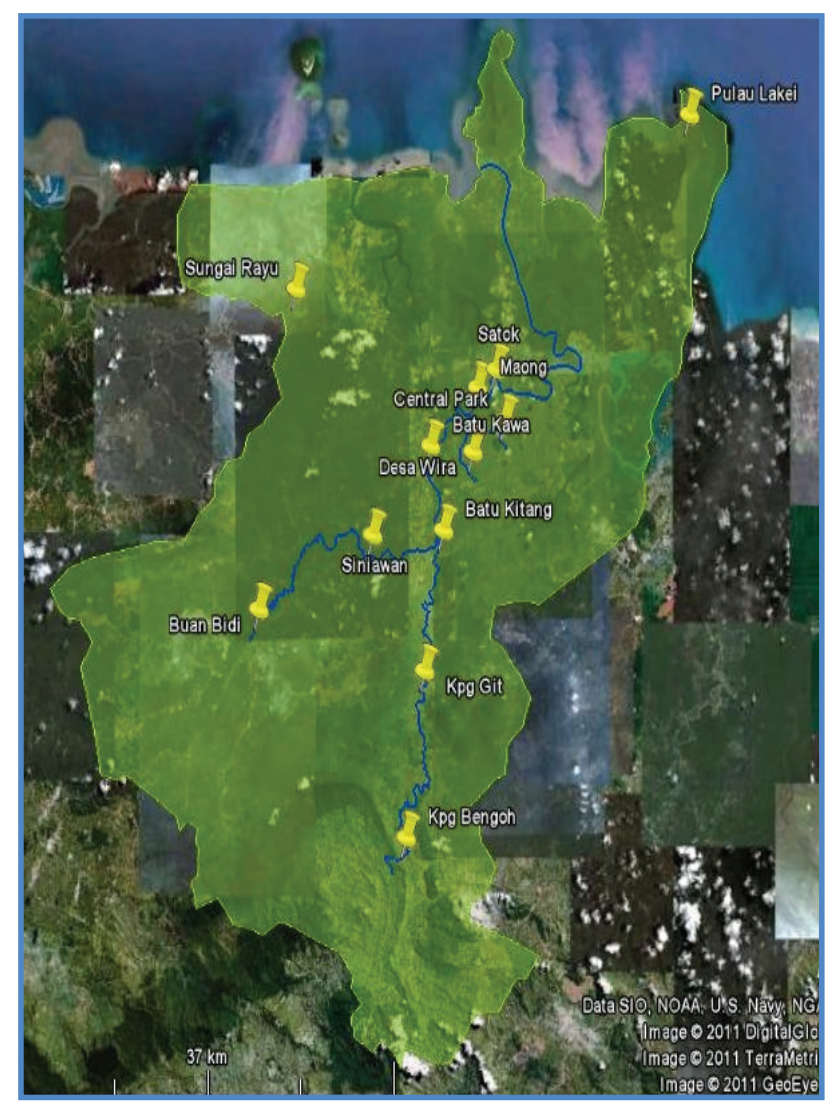

Figure 4

Delineate the Sarawak River Basin boundary, its main rivers and mark the location of water level stations in Google Earth water level stations along the rivers were inserted. Thereafter, horizontal and vertical alignments of the rivers were created, and the flood map was generated. Lastly, the map was published to Google Earth.

\section{Step 1: Delineation on Google Earth}

The first step was to delineate the Sarawak River Basin boundary, and its main rivers, including Sarawak Kiri River, Sarawak Kanan River, and Sarawak River, and to mark the location of water level stations on Google Earth (Fig. 4). This is done to ensure that these images are visible after exporting to Autocad Civil 3D.

\section{Step 2: Import Google Earth images and surfaces}

The second step was exporting the base map imagery and TIN surfaces from Google Earth to Autocad Civil 3D. Before importing TIN surface data from Google Earth, the appropriate coordinate system should be selected under the 'drawing' setting in Autocad Civil 3D. This is to ensure that the TIN surfaces are plotted correctly at the exact positions in Autocad Civil 3D.

The accuracy of the elevation data shown on the TIN surface is highly dependent on the source file imported from Google Earth. In order to achieve a TIN surface with high accuracy, the following steps are recommended:

- Sarawak River Basin boundary on Google Earth was zoomed to the allowed maximum level. Base map imagery should always point north and not be tilted while importing the TIN surface from Google Earth to Autocad Civil 3D.

\section{Step 3: Delineate main rivers and create water level surface}

The third step is delineating Sarawak River basin boundary and its river alignment using 'Polyline' function in Autocad Civil 3D. Thereafter, maximum water level data recorded since 1960 from 12 stations are inputted to Autocad Civil 3D to create the maximum water level surface. The maximum water level data obtained from DIDS are presented in Table 1.

Information on water depth at 'normal', 'alert' and 'danger' levels for 12 water level stations in Sarawak River Basin is also provided by InfoBanjir (2011) (Table 2). The aim is to alert the relevant authorities and local residents to take necessary action based on the recorded water level.

\begin{tabular}{|l|c|c|c|c|}
\hline \multicolumn{5}{|c|}{ Maximum 1 } \\
\hline $\begin{array}{l}\text { Water level } \\
\text { station }\end{array}$ & $\begin{array}{c}\text { Max. } \\
\text { water level } \\
\text { recorded } \\
\text { (m) }\end{array}$ & $\begin{array}{c}\text { Zero gauge } \\
\text { at stick } \\
\text { gauge }(\mathbf{m})\end{array}$ & $\begin{array}{c}\text { Max. water } \\
\text { level } \mathbf{( m} \\
\text { amsI) }\end{array}$ & $\begin{array}{c}\text { Date } \\
\text { recorded }\end{array}$ \\
\hline Batu Kitang & 6.699 & -1.550 & 5.149 & Jan 2004 \\
\hline Batu Kawa & 6.561 & -3.130 & 3.431 & Jan 2004 \\
\hline Buan Bidi & 7.216 & 10.167 & 17.383 & Jan 2009 \\
\hline Central Park & 3.630 & -0.130 & 3.500 & Jan 2004 \\
\hline Desa Wira & 4.815 & -0.782 & 4.033 & Jan 2009 \\
\hline Kpg. Bengoh & 10.500 & 17.496 & 27.996 & Jan 2009 \\
\hline Kpg. Git & 14.000 & 1.981 & 15.981 & Jan 2009 \\
\hline Kuala Maong & 6.234 & -2.195 & 4.039 & Jan 2004 \\
\hline Satok & 6.056 & -3.062 & 2.994 & Jan 2009 \\
\hline Siniawan & 9.960 & -2.841 & 7.119 & Jan 2004 \\
\hline Sg. Rayu & 12.030 & 1.320 & 13.350 & Jan 2009 \\
\hline Lakei & 6.570 & -1.853 & 4.717 & Jan 2004 \\
\hline
\end{tabular}




\begin{tabular}{|c|c|c|c|c|c|}
\hline \multicolumn{6}{|c|}{$\begin{array}{c}\text { Table } 2 \\
\text { Maximum water level recorded, 'normal', 'alert' and } \\
\text { 'danger' levels for the different water level stations }\end{array}$} \\
\hline Station & $\begin{array}{c}\text { Normal } \\
\text { level (m) }\end{array}$ & \begin{tabular}{|c|} 
Alert level \\
(m)
\end{tabular} & $\begin{array}{c}\text { Danger } \\
\text { level }(\mathrm{m})\end{array}$ & $\begin{array}{c}\text { Max. } \\
\text { recorded } \\
\text { water } \\
\text { level }(\mathrm{m})\end{array}$ & Indicator \\
\hline Batu Kits & 3.00 & 4.00 & 5.00 & 5.149 & Danger \\
\hline Batu Kav & 2.00 & 2.50 & 4.20 & 3.431 & Alert \\
\hline Buan Bidi & 15.00 & 16.20 & 17.80 & 17.383 & Alert \\
\hline Central Park & 3.00 & 3.90 & 4.80 & 3.500 & Alert \\
\hline Desa Wira & 1.40 & 2.80 & 3.17 & 4.033 & Danger \\
\hline Kpg. Bengoh & 27.00 & 28.00 & 29.00 & 27.996 & Normal \\
\hline Kpg. Git & 13.00 & 17.50 & 19.50 & 15.981 & Normal \\
\hline Kuala Maong & 1.00 & 2.00 & 2.80 & 4.039 & Danger \\
\hline Satok & 1.00 & 2.00 & 2.80 & 2.994 & Danger \\
\hline Siniawan & 4.00 & 5.50 & 7.20 & 7.119 & Alert \\
\hline Sg. Rayu & 10.30 & 11.00 & 11.50 & 13.350 & Alert \\
\hline Lakei & 3.00 & 3.80 & 4.50 & 4.717 & Alert \\
\hline
\end{tabular}

Referring to Table 2, it was observed that the maximum water level recorded has reached alert level for 6 stations (Batu Kawa, Buan Bidi, Central Park, Siniawan, Sg. Rayu and Lakei), and danger level for 4 stations (Batu Kitang, Desa Wira, Kuala Maong and Satok). These 10 stations are located downstream on the Sarawak River. By contrast, the maximum water level recorded for 2 stations located in the upper reaches of the Sarawak River (Kampung Git and Kampung Bengoh) only reached the 'normal' level.

\section{Step 4: Create horizontal and vertical alignments}

The fourth step is creating horizontal and vertical alignments. The function 'Create Alignment from Objects' in Autocad Civil 3D is used for creating the horizontal alignment for the rivers. Horizontal alignment is important to indicate the direction and 'horizontal curvature' of river flow. For Sarawak River Basin, 3 horizontal alignments were created, named as Sarawak Kiri River and Sarawak Kanan River, which merge at Batu Kitang Water Treatment Plant to form the Sarawak River, before flowing into the South China Sea.

Thereafter, vertical profiles of the rivers are generated using the 'Profile' function. The vertical profile shows the vertical positions of maximum water level, recorded since 1960 at 12 stations, and relates these to the existing ground elevation in the TIN surface.

\section{Step 5: Flood map generation}

Once the TIN surface (ground elevation) intersects with the maximum water level surface that was created in vertical alignment, fill and cut shades will be generated in Autocad Civil 3D. Fill shade areas are generated for the ground elevations that are lower than the maximum water level surface. These fill shades are the flood maps that represent areas covered by the floodwaters, and their extent across the Sarawak River basin. By contrast, cut shades are generally produced for ground elevations that are higher than the maximum water level surface. This area is not flooded and thus was ignored in flood map generation.

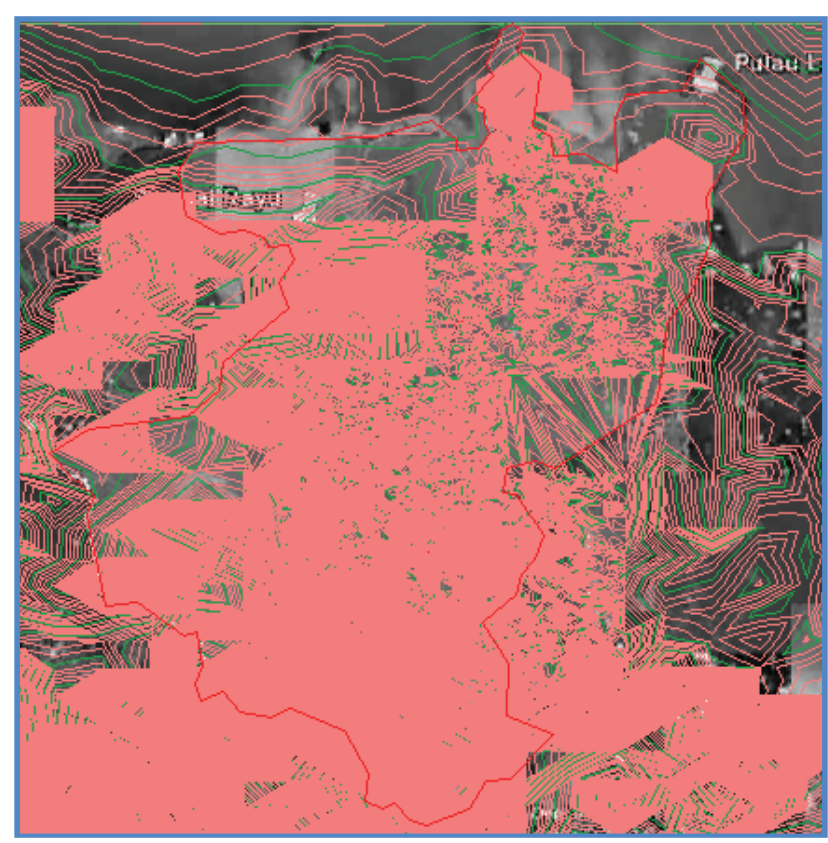

Figure 5

TIN surface of Sarawak River Basin imported from Google Earth

\section{Step 6: Publish flood map to Google Earth}

The final step for flood map generation is publication of the flood map to Google Earth, using the 'Publish to Google Earth' function in Autocad Civil 3D. The Drawing Coordinate System Transform used was pre-defined as East Malaysia (Sarawak), RSO Systems, meter, Timbalai Sarawak datum.

\section{Results and discussion}

\section{TIN surface imported from Google Earth}

Figure 5 shows the TIN surface imported from Google Earth. The contours of the ground surface were drawn at intervals of 5 feet and 25 feet, as indicated by pink and green polylines, respectively. The boundary of Sarawak River Basin is represented by a red line.

\section{Vertical profile}

Figure 6 shows the vertical profile of Sarawak Kanan River and the main river, while the vertical profile for Sarawak Kiri River

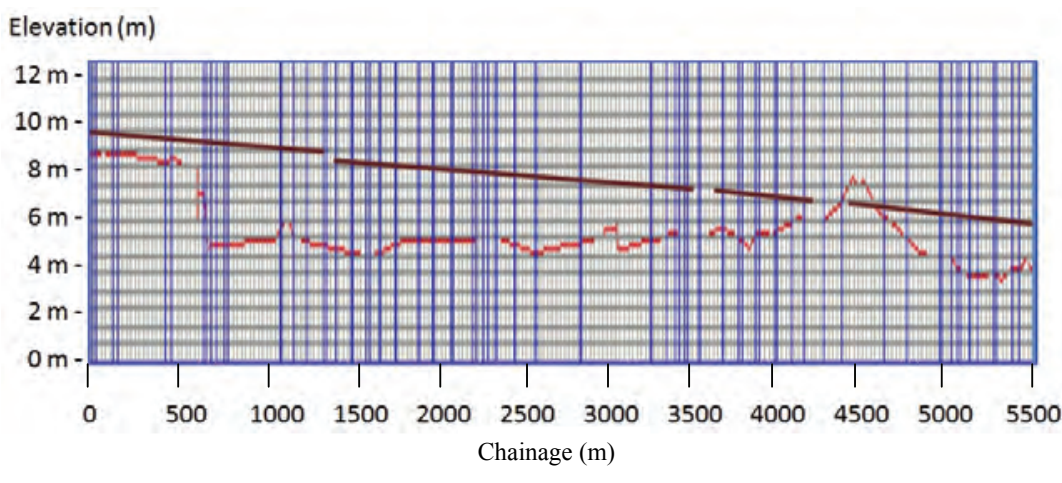

Figure 6

Vertical profile of Sarawak Kanan River and main stem of Sarawak River. Note: Brown line represents the maximum water level; red line represents the ground elevation 


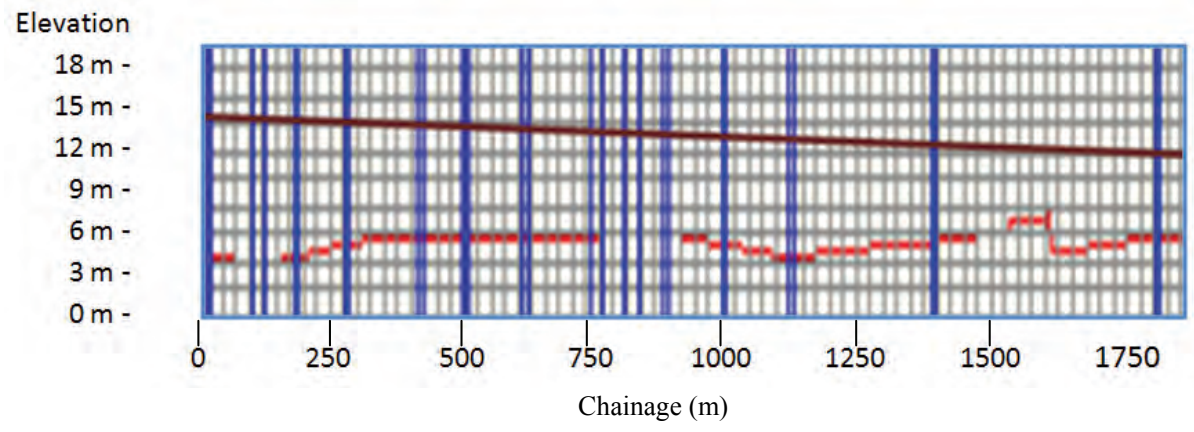

Figure 7

Vertical profile of Sarawak Kiri River. Note: Brown line

represents the maximum water level; red line represents the ground elevation

is presented in Fig. 7. Vertical profiles were utilised to check the maximum water level recorded along the river. By referring to the chainage on the horizontal alignment in Autocad Civil 3D, the maximum water level recorded at any point along the river can be determined. The declining water level (brown lines) shows the natural true gravity flow of the river, flowing

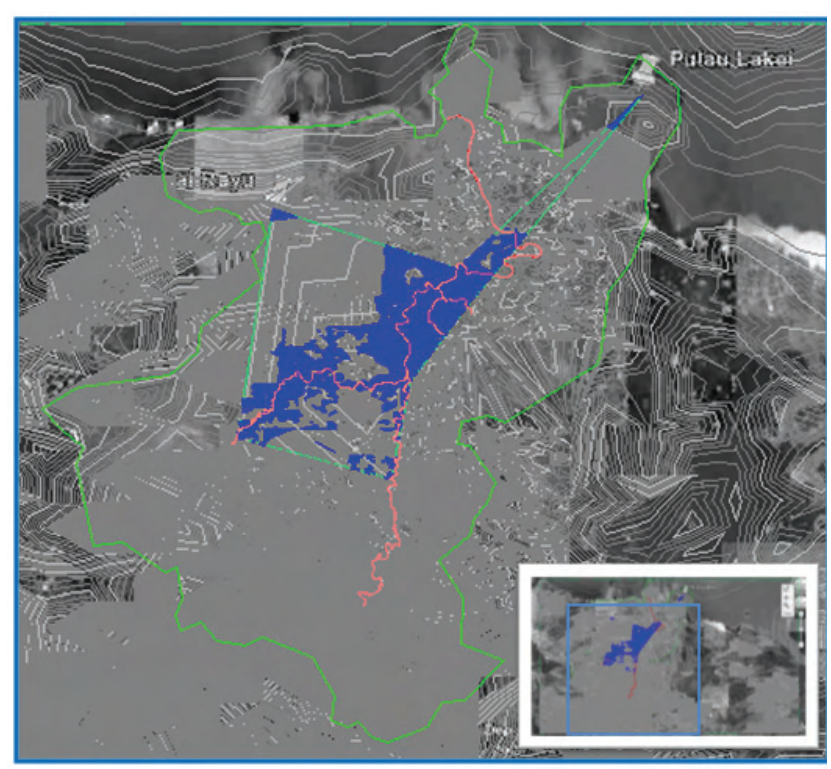

Figure 8

Flood map generated by Autocad Civil 3D

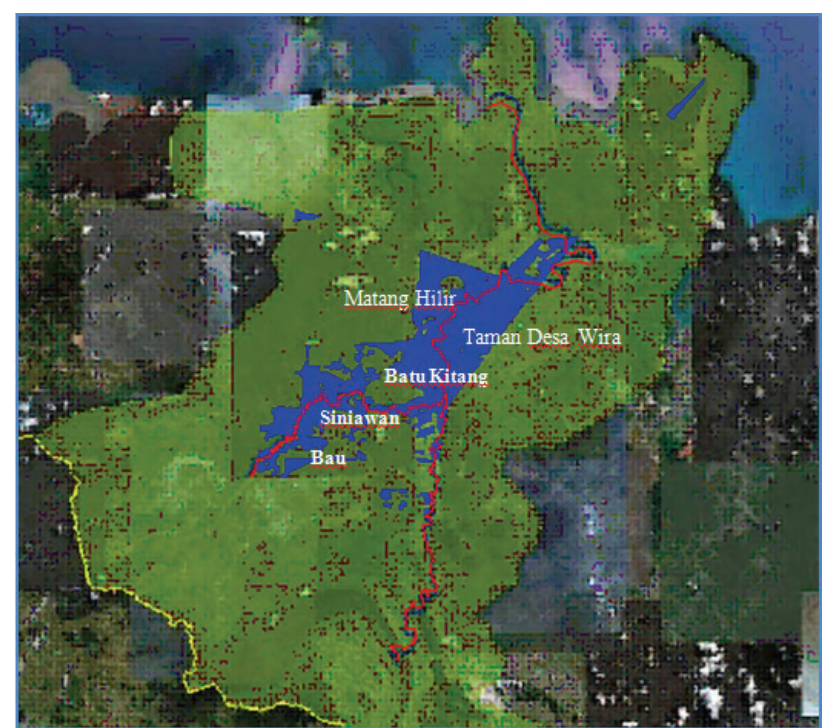

Figure 9

Publish Generated Flood Map on Google Earth from high terrain to low terrain and finally discharging into the South China Sea.

\section{0-year flood map on Autocad Civil 3D}

Figure 8 shows the flood map generated by Autocad Civil 3D. The filled areas indicated in blue are prone to flood. From the flood map it can be observed that flooding occurs in the lowlying areas, particularly along the bank of the Sarawak River. The flood map generated was then compared with flood maps generated by Mah et al. (2011) and Hii et al. (2009) to check for accuracy.

\section{Published flood map on Google Earth}

Figure 9 shows the publication of the flood map to Google Earth. Compared to the flood map published in Autocad Civil 3D, Google Earth provides more detailed geospatial information and imagery data for the Earth's surface, instead of just a map indicating the flood area. Publishing the flood map to Google Earth, enables the user to zoom in to view the extent of the flood. The map can also be adapted to address a flood alert or warning if the water level has risen to a particular level. Moreover, Google Earth can also be used to identify higher ground suitable for evacuation purposes.

\section{Comparison with other flood maps}

In order to check the accuracy of the flood map generated, it was compared with two other flood maps generated for the Sarawak River Basin, one by Mah et al. (2011) and the other by Hii et al. (2009).

\section{Flood map 2004 (Mah et al., 2011)}

The flood map generated by Mah et al. (2011) using InfoWorks RS is shown in Fig. 10a. The elevation data adopted were from detailed surveys of river cross sections and elevation data obtained from 1:50 000 topographical maps. The contour interval used in the 1:50 000 topographical map is 50 feet.

This flood map was generated based on the flood event which occured in January 2004, which is quoted as a 100-year flood event (Mah et al., 2011).

Figure 10 shows the comparison of the two maps obtained by overlaying the generated flood map on the 2004 flood map plotted by Mah et al. (2011). The areas shaded in purple are the flood-prone areas identified on the flood map produced in the current study, and areas shaded in light blue are the flood-prone areas plotted by Mah et.al. (2011). The areas shaded in blue indicate the overlapping flood-prone areas; both flood maps forecast that these areas will flood.

Table 3 presents a comparison of the size of the flooded areas for the flood map generated in this study, the flood map 


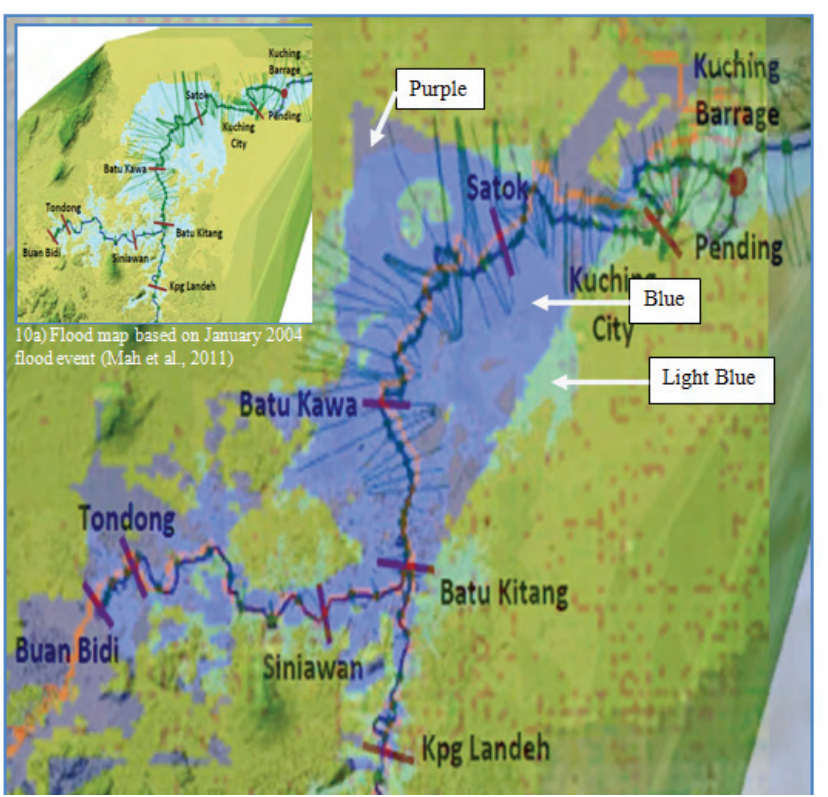

Figure 10

Comparison of flood map plotted by Mah et al. (2011) (light blue) with generated flood map (purple). Overlapping areas are shaded in blue.

\begin{tabular}{|c|c|c|}
\hline \multicolumn{3}{|c|}{$\begin{array}{c}\text { Table } 3 \\
\text { Comparison of flood area for generated flood map, map } \\
\text { plotted by Mah et al. (2011) and area covered by both flood } \\
\text { maps }\end{array}$} \\
\hline $\begin{array}{c}\text { Flood areas covered } \\
\text { by generated flood } \\
\text { map }\end{array}$ & $\begin{array}{c}\text { Flood areas plotted } \\
\text { by Mah et al. (2011) }\end{array}$ & $\begin{array}{c}\text { Flood areas covered } \\
\text { by both flood maps }\end{array}$ \\
\hline $275 \mathrm{~km}^{2}$ & $285 \mathrm{~km}^{2}$ & $255 \mathrm{~km}^{2}$ \\
\hline
\end{tabular}

plotted by Mah et al. (2011), and the flooded areas covered by both flood maps. The flooded areas for the generated flood map cover $275 \mathrm{~km}^{2}$, and the flooded areas plotted by Mah et al. (2011) cover about $285 \mathrm{~km}^{2}$. As the generated flood map overlaps with the flood area plotted by Mah et al. (2011), the flood areas indicated by both maps cover $255 \mathrm{~km}^{2}$, which is about $89 \%$ of the area covered by Mah et al. (2011).

\section{Flood Map 2009 (Hii et al., 2009)}

Hii et al. (2009)also generated a flood map for the Sarawak River Basin, using InfoWorks RS and the flood event which occured in January 2009(quoted as a 100-year flood event). A detailed cross-sectional survey of the river, and elevation data from 1:50 000 topographical maps were required for model development. The extent of the flood-prone areas is presented in Fig. 11.

The areas shaded in purple are the flood-prone areas indicated by the flood map generated in this study, and areas shaded in light blue are the flood-prone areas generated by Hii et al. (2009). Blue shading indicates the overlapping areas, which both flood maps indicate will flood.

Table 4 presents a comparison of the size of the flood-prone areas between the generated flood map, the flood map plotted by Hii et al. (2009) and the overlapping areas covered by both flood maps. The flooded areas for the generated flood map cover $275 \mathrm{~km}^{2}$, and the flooded areas plotted by Hii et al. (2009) cover $295 \mathrm{~km}^{2}$. The overlapping flood area covers $260 \mathrm{~km}^{2}$, which is about $88 \%$ of the area covered by Hii et al. (2009).

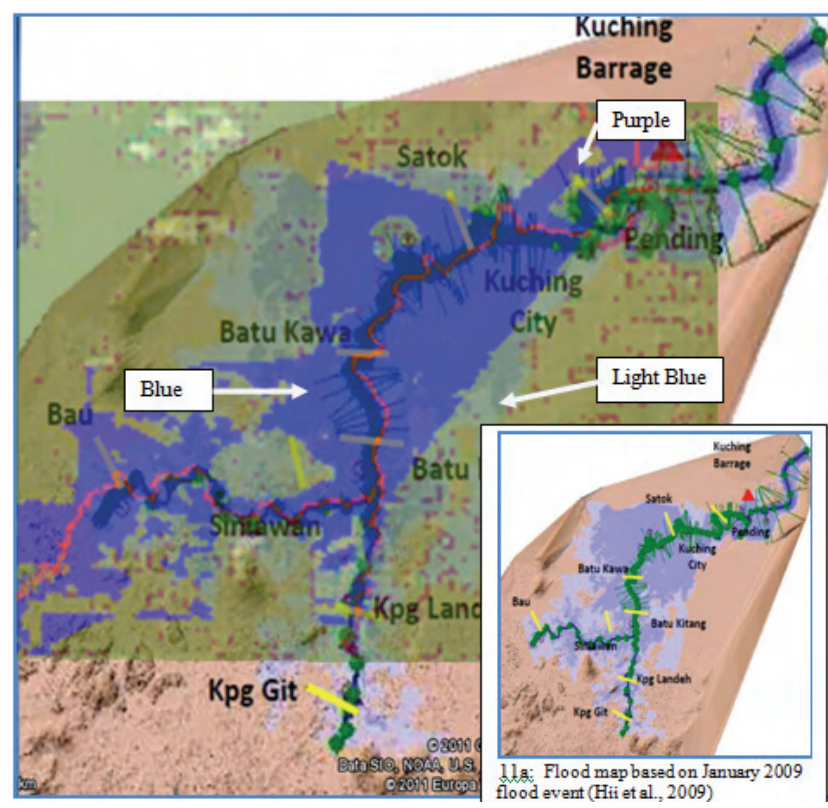

Figure 11

Comparison of flood map plotted by Hii et al. (2009) (light blue) with generated flood map (purple). Overlapping areas are shaded in blue.

\begin{tabular}{|c|c|c|}
\hline \multicolumn{3}{|c|}{$\begin{array}{c}\text { Table } 4 \\
\begin{array}{c}\text { Comparison of flood area for generated flood map, map } \\
\text { plotted by Hii et al. } \\
(2009) \text { and area covered by both flood maps }\end{array}\end{array}$} \\
\hline $\begin{array}{l}\text { Flood areas covered } \\
\text { by generated flood } \\
\text { map }\end{array}$ & $\begin{array}{l}\text { Flood areas plotted } \\
\text { by Hii et al. (2009) }\end{array}$ & $\begin{array}{l}\text { Flood areas covered } \\
\text { by both flood maps }\end{array}$ \\
\hline $275 \mathrm{~km}^{2}$ & $295 \mathrm{~km}^{2}$ & $260 \mathrm{~km}^{2}$ \\
\hline
\end{tabular}

\section{Conclusions}

The integration of Google Earth and Autocad Civil 3D has successfully constructed an economical and effective 100-year flood map for Sarawak River Basin, with tolerable discrepancies between the generated map and maps produced using detailed ground surveys and topographical maps. The good resemblance of this flood map to those generated by widelyaccepted systems suggests that Autocad Civil 3D coupled with Google Earth is a suitable method to replace current flood mapping systems in Sarawak River Basin. This implies a new milestone in flood mapping as the current method is very expensive and local authorities are not able to afford to generate the flood map throughout the state using the same method. The method developed here also represents a new technique for constructing flood maps, for learners, educators, researchers and water users.

However, there are certain limitations inherent in the method that will reduce the accuracy and functionality of the generated flood map. According to Farr et al. (2007), the limitations of Google Earth are:

- SRTM data has an absolute error of smaller than $20 \mathrm{~m}$ and a relative error of smaller than $15 \mathrm{~m}$.

- The elevation capturing method used is not able to pass through the water surface or vegetation and hence may overestimate elevation in areas with thick forests.

- The images of Google Earth are not placed at the correct coordinates or stitched properly to adjacent images. 
Every 1 to 3 years, Google Earth will update the imagery database with the highest resolution imagery possible (Google Earth, 2011). The DEM data could be updated at this point, thus incorporating changes brought about by development as well as catastrophes, at no additional cost, enabling the production of more accurate flood maps for river basins across the world.

\section{References}

ACA PACIFIC (2012) AutoCAD® Civil 3D 2010. URL: http://www. acapacific.com.my/files/product/product 12 1.pdf (Accessed 15 December 2012).

BUSTAMI R, BONG C, HAMSAH NAF and ADAM JH (2011) Flood mapping of Sarawak River sub-basins. Proc. ASEAN Australian Engineering Congress (AAEC2011), 25-27 July 2011, Kuching, Sarawak.

DEPARTMENT OF IRRIGATION AND DRAINAGE SARAWAK (2011) Historical flood events recorded in Sarawak from 19462009. URL: http://www.did.sarawak.gov.my/flood/hflood46-96. htm (Accessed 28 September 2011).

FARR, TOM G, ROSEN PA, CARO E, CRIPPEN R, DUREN R, HENSLEY S, KOBRICK M, PALLER M, RODRIGUEZ E, ROTH L, SEAL D, SHAFFER S, SHIMADA J, UMLAND J, WERNER M, OSKIN M, BURBANK D and ALSDORF D (2007) SRTM Validation - the Shuttle Radar Topography Mission. The Global Science Gateway. URL: Worldwidescience.org (Accessed 15 October 2011).
GOOGLE EARTH COMMUNITY (2006) Nov. $23^{\text {rd }}$ - Thanksgiving Day imagery update. URL: http://bbs.keyhole.com/ubb/ubbthreads. php?ubb=showthreaded\&Number $=695033 \&$ site $\mathrm{id}=1$ \#import (Accessed 20 December 2011).

GOOGLE EARTH (2011) Understanding Google Earth imagery. URL: http://earth.google.com/support/bin/answer. py?hl=en\&answer=176147 (Accessed 28 September 2011).

HII CP, PUTUHENA FJ and SAID SB (2009) Adaptive Logical Framework For Integrated Flood Management Along Sarawak River. Int. J. Hydro-Clim. Eng. 1 17-36.

INFOBANJIR (2011) On-Line River Level Data (m) - above Mean Sea Level, DIDS. URL: http://202.168.71.35/sarawakw.asp (Accessed 16 November 2011).

JONES JL (2004) Mapping a flood...before it happens. U.S. Geological Survey Fact Sheet 2004-3060. URL: http://pubs.usgs.gov/ fs/2004/3060/pdf/fs20043060.pdf (Accessed 8 August 2011).

KTA TENAGA SDN BHD (2003) Flood Map National Register of River Basin. Vol. 2.10. Department of Irrigation and Drainage (DID), Malaysia.

MAH DYS, HII CP, PUTUHENA FJ and LAI SH (2011) River modelling to infer flood management framework. Water SA 37 (1) 121-126.

RIVER BASIN INITIATIVE MALAYSIA (2002-2011)

Climate. URL: http://www.riverbasin.org/index. cfm?\&menuid=81\&parentid=51 (Accessed 11 September 2011).

WORLD WEATHER AND CLIMATE INFORMATION (2010-2011) Average rainfall in Kuching, Malaysia. URL: http://www.weatherand-climate.com/average-monthly-precipitation-Rainfall, Kuching, Malaysia (Accessed 25 September 2011). 
http://dx.doi.org/10.4314/wsa.v39i1.18 Available on website http://www.wrc.org.za

ISSN 0378-4738 (Print) = Water SA Vol. 39 No. 1 January 2013 ISSN 1816-7950 (On-line) = Water SA Vol. 39 No. 1 January 2013 